\title{
Proses Pembelajaran Daring Guru Menggunakan Aplikasi Whatsapp Selama Pandemik Covid-19
}

\author{
Teguh Prasetyo', Zulela M.S. ${ }^{2}$ \\ 1 Universitas Djuanda Bogor, Bogor, Indonesia \\ ${ }^{2}$ Universitas Negeri Jakarta, Jakarta, Indonesia \\ *Corresponding author: teguh@unida.ac.id
}

\begin{abstract}
The learning process online during the Covid-19 pandemic was one of the main changes to the pedagogical competencies that teachers in elementary schools must master. Teachers innovate in every online learning so that students remain enthusiastic and highly motivated by the material presented during learning. Researchers used a case study approach to explore the implementation of online learning from May to June 2020. The subjects studied were three elementary school teachers as well as key research informants. Collection procedure with indepth interviews, related to the process of implementing online learning during the Covid-19 pandemic. The activity of analyzing and presenting the research data was carried out in a descriptive qualitative manner with the help of the nvivo 12 plus application. The results of research on the teacher's online learning process are still ongoing with the WhatsApp application. The teacher combines online learning innovations through the WhatsApp application with PjBL, PBL, and YouTube videos. Furthermore, the new findings of the process of implementing online learning with WhatsApp go through three stages, namely: communicating, delivering, and collecting student learning assignments. The teacher's online learning process maintains the interaction between the teacher and students to achieve the maximum possible learning outcomes with a variety of supporting applications.
\end{abstract}

Keywords: covid-19 pandemic; learning process; online learning; teachers; whatsapp

\section{ABSTRAK}

Proses pembelajaran dalam jaringan di masa pandemik Covid-19 menjadi salah perubahan utama pada kompetensi pedagogik yang harus dikuasai guru di sekolah dasar. Guru berinovasi dalam setiap pembelajaran daring agar siswa tetap semangat dan motivasi yang tinggi dengan materi pembelajaran yang disajikan selama pembelajaran. Peneliti menggunakan pendekatan studi kasus untuk mengeksplorasi pelaksanaan pembelajaran daring pada bulan Mei sampai Juni 2020. Subjek penelitian merupakan tiga orang guru sekolah dasar sekaligus sebagai informan kunci penelitian. Prosedur pengumpulan dengan wawancara mendalam terkait proses pelaksanaan pembelajaran daring selama pandemik Covid-19. Kegiatan analisis dan penyajian data hasil penelitian dilakukan secara deskriptif kualitatif dengan nvivo 12 plus. Hasil penelitian proses pembelajaran daring guru tetap berlangsung dengan aplikasi WhatsApp. Guru memadukan inovasi pembelajaran daring melalui aplikasi WhatsApp dengan PjBL, PBL, dan video youtube. Selanjutnya temuan baru proses pelaksanaan pembelajaran daring dengan WhatsApp melalui tiga tahapan yaitu: berkomunikasi, penyampaian, dan pengumpulan tugas belajar siswa. Proses pembelajaran daring guru tetap mempertahankan interaksi antara guru dan siswa untuk mencapai hasil belajar semaksimal mungkin dengan berbagai aplikasi yang mendukung.

Kata Kunci: guru; pandemik covid-19; pembelajaran daring; proses pembelajaran; whatsapp

\section{Pendahuluan}

Pembelajaran dalam jaringan atau yang diakronimkan dengan Daring pada masa pandemik Covid-19 menjadi hal menarik dan tantangan bagi pendidikan di Indonesia khususnya para guru di sekolah dasar. Pembelajaran daring merupakan salah satu solusi untuk menerapkan Social distancing guna mencegah mata rantai penyebaran wabah Covid-19, karena pembelajaran daring mampu memberikan jarak antara siswa dan siswa untuk belajar dimanapun dan kapanpun sehingga dapat menghindari kerumunan atau berkumpul dengan 
teman sebaya (Handarini \& Wulandari, 2020). Menariknya pembelajaran daring dilaksanakan masih banyak masyarakat Indonesia yang masih terlihat gagap teknologi atau gaptek baik ditingkat pengajar maupun pada wali siswa sehingga proses pembelajaran tidak berlangsung secara cepat. Bagi guru yang memiliki keterampilan pada literasi digital dapat membantu siswanya dan para orang tua secara langsung. Selain itu, peran orang tua "Mau tidak mau" harus terlibat langsung dalam proses pembelajaran yang dilaksanakan guru secara daring.

Permasalahan "gagap teknologi", guru menyisakan permasalahan karena proses pelaksanaan pembelajaran daring harus tetap berlangsung. Dimana jarak menjadi kondisi yang harus dihadapi, baik siswa dan guru harus melaksanakan pembelajaran di rumah masing-masing dengan interaksi menggunakan media Teknologi Informasi dan Komunikasi (TIK). Oleh karena itu, dibutuhkan secara tepat dan efektif. Adapun solusinya pembelajaran daring untuk menunjang kemajuan belajar siswa di rumah dalam kondisi pandemi Covid-19 dengan memaksimalkan peran orang tua di rumah untuk mendampingi putra-putrinya belajar mandiri di rumah masing-masing (Anugrahana, 2020). Pernyataan yang hampir senada bahwa pembelajaran daring dapat dikatakan menjadi satu-satunya pilihan pembelajaran yang dapat dilakukan oleh pendidik untuk meningkatkan mutu pembelajaran di Indonesia (Purwasih et al., 2020). Selain itu, pembelajaran daring merupakan usaha guru untuk tetap mengikuti aturan pemerintah Indonesia, dimana siswa tidak diizinkan untuk belajar secara langsung ke sekolah dan wajib melaksanakan pembelajaran secara daring dengan memanfaatkan aplikasi pembelajaran daring yang ada.

Tantangan pembelajaran daring yang harus dihadapi guru terkait kemampuan guru dalam menguasai teknologi, sumber daya manusia, sarana prasarana yang dapat mendukung proses pembelajaran daring. Untuk itu rekomendasi yang harus dilakukan adalah membangun kemitraan antara orang tua, guru, dan stakeholder secara berkelanjutan. Serta perlu adanya evaluasi terhadap proses pembelajaran daring agar tujuan dan hasilnya bisa tercapai secara optimal (Jamilah, 2020). Pembelajaran daring memiliki dampak langsung pada siswa diantaranya ketersediaan sarana dan prasarana yang kurang memadai, perbedaan atmosfer saat belajar di kelas dengan belajar di rumah sehingga berpengaruh pada motivasi belajar siswa dan kecenderungan gaya belajar siswa yang visual atau tulisan (Satrianingrum \& Prasetyo, 2020).

Pembelajaran daring harus dipersiapkan maksimal oleh guru agar hasil belajar siswa tetap optimal walaupun siswa belajar dari rumah. Proses pembelajaran merupakan interaksi yang melibatkan antara guru dan siswa dalam waktu dan tempat bersamaan. Namun dikala pandemik Covid-19 guru dan siswa tidak dapat melaksanakan tatap muka secara langsung. Pemilihan beberapa metode pembelajaran yang digunakan oleh guru di dalam kelas harus diubah menjadi pembelajaran daring yang dilaksanakan dengan aplikasi pembelajaran daring. Pembelajaran dilakukan di rumah masing-masing dengan sistem daring dilaksanakan dengan dua cara memberikan isi materi belajar dan penugasan dengan perangkat atau aplikasi daring. Selain itu, para guru meminta kepada siswa untuk aktif dalam menonton, menyimak, memahami, dan menjawab soal yang diberikan selama proses pembelajaran yang ditayangkan oleh stasiun TVRI.

Model pembelajaran daring dapat dilakukan dengan cara menyesuaikan kebutuhan setiap sekolah yang sudah siap dalam pelaksanaan pembelajaran daring dengan menggunakan Teknologi Komunikasi dan Informasi (TIK) seperti: google classroom, rumah 
belajar, zoom, video conference, WA grup orang tua dan guru, telepon atau live chat dan lainnya (Jamilah, 2020). Selain memiliki kelebihan, pembelajaran daring memiliki tantangan khusus, diantaranya lokasi guru dan siswa yang terpisah saat melaksanakan pembelajaran sehingga tidak dapat mengawasi secara langsung selama proses pembelajaran (Sadikin, A., \& Hamidah, 2020), penugasan belajar siswa dibantu oleh orang tua (Satrianingrum \& Prasetyo, 2020), tantangan capaian hasil belajar dan pendidikan karakter siswa selama pandemik (Santika, 2020) tidak semua sekolah memiliki sumber daya yang cukup dan tidak semua anak memiliki akses internet (Morgan, 2020) kebutuhan sarana dan prasarana belajar yang memadai (Handarini \& Wulandari, 2020).

Di era ini, peningkatan media sosial begitu cepat siswa harus didorong pada pengintegrasian pembelajaran informal dengan pembelajaran formal menggunakan aplikasi WhatsApp (Annamalai, 2019). WhatsApp merupakan salah satu aplikasi ponsel dan jejaring sosial berbasis web yang terintegrasi dengan berbagai fitur yang digunakan untuk berkomunikasi dengan pengguna lain, mulai dari pendidikan, bisnis, dan hiburan yang dikembangkan situs jejaring sosial ini (Nihayati \& Indriani, 2021). Secara komprehensif dapat dipahami bahwa aplikasi WhatsApp berfungsi sebagai platform yang digunakan untuk berpartisipasi dalam kegiatan sosial dan komunikasi (Elareshi et al., 2020). Penelitian ini bertujuan untuk memberikan eksplorasi yang diperoleh peneliti tentang proses dan tahapan pembelajaran daring menggunakan aplikasi WhatsApp selama pandemik Covid-19 dengan melakukan wawancara tiga guru di sekolah dasar yang ada di Kota dan Kabupaten Bogor, Jawa Barat.

\section{Proses Pembelajaran}

Proses pembelajaran dapat dimaknai sebagai komunikasi guru dengan siswa. Proses pembelajaran mengandung merupakan proses lima komponen komunikasi, guru (komunikator), bahan pembelajaran, media pembelajaran, peserta didik (komunikan), dan tujuan pembelajaran (Sukandi \& Maulana, 2020). Proses pembelajaran tidak hanya pada aspek guru namun juga membutuhkan kemandirian siswa. Belajar yang dilakukan secara mandiri sangat diperlukan dalam pembelajaran daring, karena proses pembelajaran, siswa harus mencari, menemukan, dan menyimpulkan sendiri atas apa yang telah dipelajari serta belajar mandiri merupakan motivasi penunjang keberhasilan dalam proses pembelajaran daring (Handarini \& Wulandari, 2020).

Aktivitas belajar siswa dalam proses pembelajaran dapat dilakukan mulai dengan cara melakukan diskusi isi video pembelajaran, mempraktikkan materi video, dan membuat produk media pembelajaran inovatif berdasarkan materi yang telah dijelaskan guru dalam pembelajaran (Batubara \& Batubara, 2020). Sebenarnya proses pembelajaran dapat terjadi di rumah dan di sekolah maupun di masyarakat. Oleh karena itu semua bisa berjalan dengan baik, dengan dukungan fasilitas pembelajaran yang mendukung seperti internet (Dewi, 2020). Peran guru dalam memberikan bimbingan dengan metode konsultasi dapat meningkatkan kompetensi melaksanakan proses pembelajaran daring dan luring siswa sekolah dasar (Malyana, 2020). Perubahan arah pembelajaran dari teacher centered menjadi student centered menjadi dasar proses pembelajaran jarak jauh, dimana pembelajaran yang dilaksanakan lebih menekankan pada bagaimana keaktifan siswa dalam mencari pengalaman baru dalam proses belajar tanpa dibatasi ruang dan waktu (Hanik, 2020). 
Kondisi tersebut menuntut para guru untuk melakukan inovasi dalam proses pembelajaran khususnya pembelajaran melalui daring (dalam jaringan). Solusi yang dilakukan selama masa pandemi adalah pemanfaatan aplikasi WhatsApps digunakan guru sebagai sarana untuk mengumpulkan tugas. Alasan guru memilih menggunakan WhatsApp karena faktor lebih praktis, lebih mudah dipahami anak, lebih efektif, tidak banyak kuota, bukan hal yang asing, dan mudah bagi semua orang tua wali siswa (Anugrahana, 2020).

Proses pembelajaran klasikal selama pandemik berbeda dengan penerapan pembelajaran sebelum pandemik Covid-19. Pelaksanaaan pembelajaran sebelum pandemik meliputi: (1) kegiatan penyajian bahan pelajaran secara klasikal dengan ceramah bervariasi, (2) mengasosiasikan bahan pelajaran melalui keterhubungan materi dengan situasi nyata, (3) mengaplikasikan materi yang telah dipelajari dengan mengerjakan soal dan menjawab pertanyaan, dan (4) membuat kesimpulan materi belajar oleh siswa dengan bimbingan guru (Ruhimat, 2010). Proses pembelajaran di masa pandemik Covid-19 lebih sederhana yakni, tahapan berkomunikasi, penyampaian, dan pengumpulan tugas belajar siswa.

\section{Pembelajaran Dalam Jaringan (Daring)}

Pembelajaran dalam jaringan sering juga disebut online learning, menurut Riyana, (2015) pembelajaran ini merupakan suatu sistem yang dapat memfasilitasi siswa belajar lebih luas, lebih banyak, dan bervariasi. Menurut (Wong, 2020)“...online learning is education that takes place over the internet synchronously and/or asynchronously and does not take place in a traditional classroom. It can be in the form of online videos, online learning materials, face-to-face meeting sessions, interactive online questions, quizzes and practices". Pembelajaran daring secara keseluruhan bergantung pada perangkat teknologi dan internet, pengajar dan siswa dengan koneksi internet yang buruk cenderung ditolak aksesnya ke pembelajaran online (Adedoyin \& Soykan, 2020) dan masalah utama dalam desain pembelajaran online yang efektif termasuk pendekatan pedagogis yang akurat, tugas yang relevan dan otentik, serta alat dan teknologi yang sesuai (Carrillo \& Flores, 2020). Selain itu, fasilitas pembelajaran dapat digunakan siswa dapat belajar kapan dan dimana saja tanpa terbatas oleh jarak, ruang dan waktu serta materi pembelajaran juga lebih bervariasi, seperti visual, audio, dan gerak (Riyana, 2015). Jadi, pembelajaran daring merupakan desain pembelajaran menggunakan internet baik dalam bentuk sinkronus dan asinkronus untuk memfasilitasi belajar siswa dengan media pembelajaran yang bervariasi secara online.

Bentuk pembelajaran daring berupa video online, materi pembelajaran online, sesi tatap muka, pertanyaan online interaktif, kuis dan praktik atau projek. Bagi pendidik dalam melakukan sharing materi pada siswa mahasiswa dengan cara mengunggah isi materi belajar, melakukan diskusi pada fitur forum chatting, webinar, dan teleconference ((Prasetyo et al., 2016)). Implikasi Perubahan proses pembelajaran tradisional ke pembelajaran online dapat berdampak negatif pada anak-anak sekolah dasar yang lebih kesulitan beradaptasi dengan lingkungan belajar yang baru (Kruszewska et al., 2020)

\section{Metode Penelitian}


Penelitian ini merupakan penelitian kualitatif dengan menggunakan metode studi kasus. Studi kasus melibatkan pembahasan subjek penelitian dengan pengumpulan data secara keseluruhan dan prosedur pencatatan (Creswell, 2014). Lebih lanjut Creswell, langkahlangkah analisis data dan metode yang digunakan untuk menyajikan data, menafsirkannya, memvalidasinya, dan menunjukkan hasil potensial dari penelitian. Subjek penelitian merupakan tiga orang guru yang ada di Kabupaten dan Kota Bogor sekaligus menjadi informan penelitian. Pelaksanaan pengambilan data selama Mei sampai Juni 2020 ketika pandemik masih berlangsung di Indonesia. Prosedur pengumpulan data dilakukan dengan melakukan wawancara mendalam (In-depth Interview) terhadap fokus penelitian, yakni proses pelaksanaan pembelajaran daring guru Sekolah Dasar selama pandemik Covid-19. Kegiatan analisis dan penyajian data hasil penelitian dilakukan secara deskriptif dengan berbantuan Nvivo 12 plus. Keabsahan data dilakukan dengan konfirmasi kepada sumber informan penelitian.

\section{Hasil dan Pembahasan}

Kondisi pandemik karena pandemik Covid-19 saat ini membuat guru harus berpikir bagaimana caranya agar guru tetap menyampaikan materi dan tugas kepada siswa, kemudian mengevaluasi hasil pembelajaran. Guru menyampaikan materi mulai dari memberikan motivasi belajar kepada siswa yang tujuannya agar siswa semangat dalam mengikuti pembelajaran, walaupun dengan kondisi pandemik Covid-19. Proses menyampaikan isi materi belajar dilaksanakan dengan cara memberikan pembelajaran menggunakan pembelajaran jarak jauh. Hasil penelitian yang telah lakukan mengenai proses dan model pembelajaran apa saja yang dapat dilakukan oleh guru selama Covid-19.

\section{1) Model pembelajaran Daring Aplikasi WhatsApp Dipadukan dengan Model Pembelajaran Project Based Learning (PjBL)}

Pelaksanaan model ini terdapat di SDN Banjarsari 1 Kabupaten Bogor dilakukan secara online, seperti memberi tugas dari buku paket setiap harinya kepada siswa. Pengisian daftar hadir dilakukan melalui grup WhatsApp, begitu pula dengan hasil pembelajaran atau tugas yang telah diselesaikan siswa mengumpulkan melalui grup WhatsApp berupa sebuah Foto. Menurut guru kelas (ST), proses pembelajaran menggunakan model PjBL ini siswa diperintahkan oleh guru membentuk sebuah produk atau sebuah proyek. Biasanya model pembelajaran PjBL dilakukan secara berkelompok, dikarenakan saat ini terjadi wabah Covid19 yang mengharuskan siswa belajar di rumah masing-masing. Agar model pembelajaran berlangsung secara efektif, pertama guru meminta siswa membaca terlebih dahulu materi pembelajaran yang terdapat di buku, guru memberikan penjelasan mengenai produk atau proyek yang akan dibuat siswa.

Meskipun guru sudah menjelaskan mengenai materi yang diajarkan, pembelajaran daring yang menggunakan model PjBL ini tidaklah mudah, karena siswa setelah diberi penjelasan sekali tidak semua anak mengerti, maka guru harus menjelaskannya secara berulang-ulang. Kekurangan dari pembelajaran ini pun dikarenakan pembelajaran di rumah, siswa tidak sepenuhnya mengerjakan sendiri banyak yang dibantu oleh oleh orangtuanya. Menurut guru, proses pembelajaran daring yang dilakukan siswa tidak sepenuhnya mengerjakan sendiri banyak yang dibantu oleh orangtuanya. Ditambahkan lagi dari hasil wawancara, guru menyatakan bahwa pembelajaran yang efektif yaitu secara tatap muka langsung di sekolah. 


\section{2) Model pembelajaran Daring Aplikasi WhatsApp Dipadukan dengan Model Pembelajaran Problem Based Learning (PBL)}

Selama pembelajaran daring di Sekolah Dasar Alam Al Giva Kota Bogor. Proses pembelajaran daring dipadukan dengan PBL selama Pandemik ini tetap menyenangkan, mudah, dan dapat mencapai tujuan pembelajaran. Menurut guru kelas (NW) memutuskan untuk menggunakan model pembelajaran PBL dikemas melalui Project with parents. Maksud dengan Project with parents adalah mencoba mengaitkan materi pembelajaran agar dapat dilakukan bersama dengan orang tua selaku pendamping siswa selama pembelajaran di rumah. Semisal ketika materi pengukuran, guru memberikan materi terlebih dahulu berupa video pembelajaran. Kemudian NW mempergunakan zoom untuk menyapa para siswa sebelum dimulainya pembelajaran dan memberikan pemahaman awal kepada siswa. Jadi, siswa akan merasakan suasana pembelajaran seperti layaknya di sekolah.

Proses pembelajaran yang dilaksanakan guru menggunakan aplikasi WhatsApp dan google classroom berbasis PBL. Untuk melakukan pembelajaran seperti itu tentunya diperlukan kerjasama antara seluruh stakeholder. Karena tugas memberikan pembelajaran bukan hanya tugas utama guru, melainkan tugas seluruh stakeholder baik orang tua siswa maupun lingkungan tempat siswa, yakni masyarakat sekitar. Hasil wawancara guru bahwa fasilitas sangat berpengaruh terhadap keberhasilan pembelajaran daring ini namun kerjasama antara seluruh stakeholder sekolah pun tidak kalah penting. Bagi sekolah fasilitas pembelajaran daring tidak mendukung ketika proses pembelajaran guru dapat mempergunakan model pembelajaran berbasis lingkungan dan lingkungan sekitar sebagai media pembelajaran.

\section{3) Model pembelajaran Daring Aplikasi WhatsApp Dipadukan dengan Video Pembelajaran dari Youtube}

Pembelajaran daring menggunakan aplikasi WhatsApp di MI Sirojul Athfal Kota Bogor, adapun alasan pemilihan WhatsApp karena mudah digunakan. Proses pelaksanaan pembelajaran daring dimulai dari guru memberikan materi berupa video pembelajaran yang berasal dari youtube ataupun video yang dibuat oleh sendiri. Tugas yang diberikan tidak selalu berbentuk soal tetapi dikombinasikan dengan pengaplikasian dalam kehidupan seharihari. dan dikirimkan melalui grup WhatsApp kelas. Bagi siswa yang tidak memiliki android siswa boleh menumpang ke temannya atau bisa mendatangi guru untuk menanyakan pembelajaran yang belum dipahami dan mengumpulkan tugasnya secara langsung. Menurut wali kelas, (SK) dalam menyampaikan isi materi disampaikan di grup WhatsApp tersebut. Guru menyampaikan materi mulai dari memberikan motivasi belajar kepada siswa yang tujuannya agar siswa semangat dalam mengikuti pembelajaran, walau dengan kondisi yang seperti ini kegiatan belajar mengajar harus tetap bisa memotivasi siswa untuk belajar. Selain itu, guru memberikan arahan dan pengertian mengenai bahayanya virus Covid-19 ini, dan mengingatkan siswa untuk selalu menjaga kebersihan dengan cara mencuci tangan, menggunakan masker, jangan berkumpul jika tidak ada kepentingan, dan sebagainya.

Agar siswa tidak merasa bosan dengan materi yang disampaikan, guru sering mencarikan video pembelajaran dari youtube yang berkaitan dengan materi ajar. Hal ini menjadi proses pembelajaran menyenang bagi siswa. Selain menyenangkan materi yang berupa video akan sangat mudah bagi siswa untuk menangkap materi yang diajarkan. Bukan hanya itu, untuk mengevaluasi hasil belajar siswa, guru memberikan latihan soal berupa kuis yang dibuat oleh guru di google forms, serta mengirimkan hasil tugas dalam bentuk atau dokumen ke grup 
WhatsApp. Kegiatan menilai keterampilan dan sikap siswa, guru menginstruksikan siswa untuk membuat video aktivitas siswa selama di rumah setiap hari, contohnya seperti merekam serta membuat video hafalan surah-surah pendek, melaksanakan pekerjaan rumah dan lain sebagainya kemudian dikirim ke grup WhatsApp.

Berikut ini hasil visualisasi penelitian terkait proses pembelajaran daring guru sekolah dasar yang ditemukan peneliti.

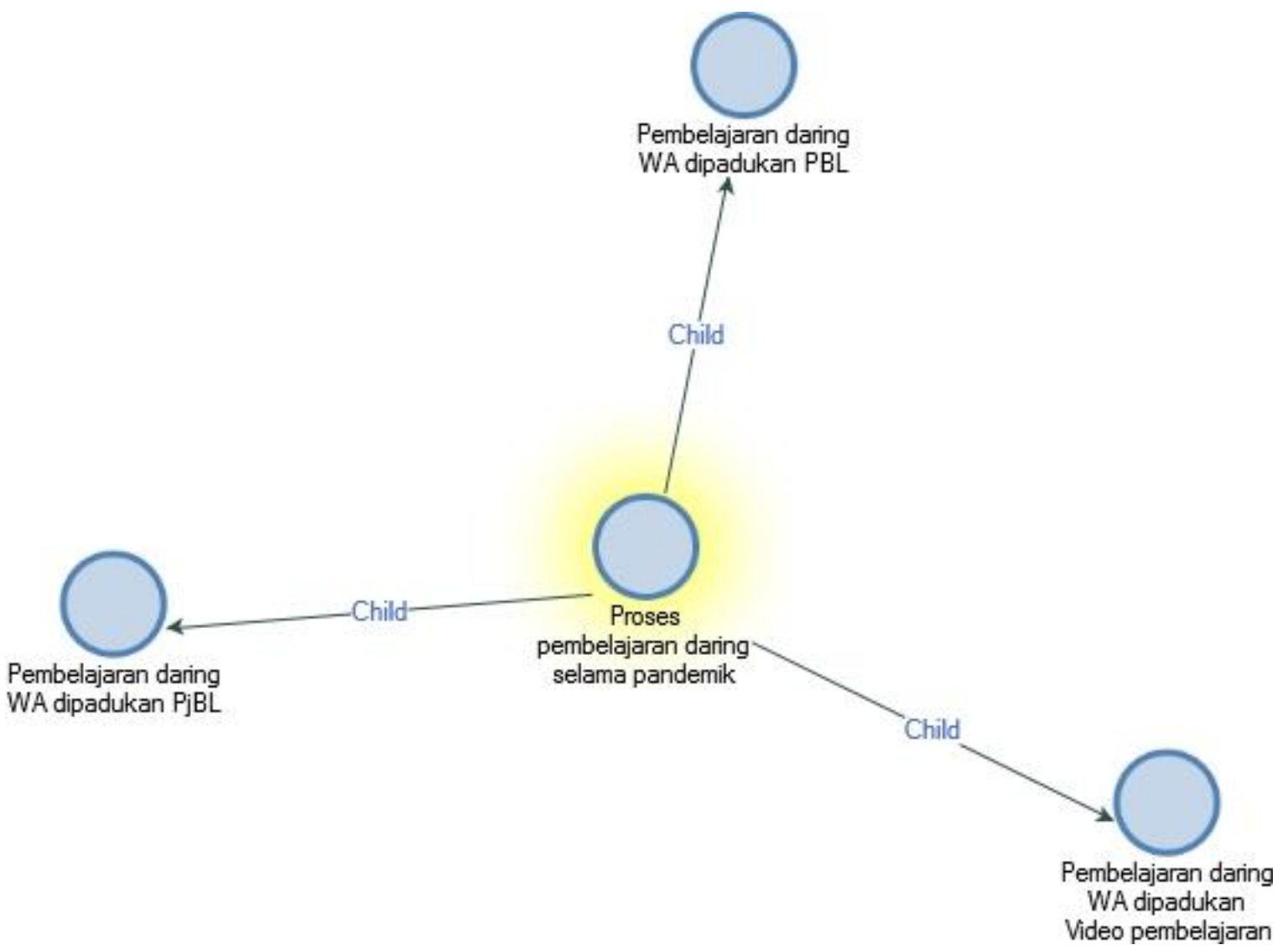

Gambar 1. Proses Pembelajaran Daring selama Pandemik Covid-19

Informasi tambahan yang diberikan guru mengenai kendala utama proses pembelajaran daring selama pandemik Covid-19, yakni terkait fasilitas sekolah masih kurang, tidak semua siswa dan orang tua memiliki handphone (hp), terbatasnya kuota internet sehingga target capaian pembelajaran kurang maksimal dan guru kesulitan mengukur hasil belajar siswa.

Hasil temuan penelitian yang telah diungkapkan di atas, proses pembelajaran yang dilaksanakan guru dengan siswa di tiga sekolah yakni SDN Banjarsari 01, Sekolah Dasar Alam Al Giva, dan MI Sirojul Athfal dilaksanakan menggunakan model pembelajaran daring. Pembelajaran daring menggunakan bantuan aplikasi WhatsApp yang dipadukan dengan pembelajaran lain seperti pembelajaran berbasis proyek atau PjBL. Dalam implementasi pembelajaran PjBL dilaksanakan dengan memberikan tugas proyek yang dapat dilaksanakan secara mandiri di rumah selama pandemik Covid-19. Guru merasa bahwa model PjBL sangat bermanfaat untuk pembelajaran membuat dan menghasilkan sebuah produk-produk tertentu seperti kolase serta siswa merasa senang dengan tugas membuat produk dan menemukan ideide baru (Altaftazani et al., 2020). Pelaksanaan pembelajaran online berbasis proyek ini memberikan peluang kepada siswa untuk mempelajari konsep secara mendalam sekaligus 
juga dapat meningkatkan hasil belajar mereka (Abidin et al., 2020). Namun yang harus diperhatikan pada penerapan model PjBL yakni membutuhkan persiapan yang matang, dalam memilih topik yang tepat sesuai sehingga kreativitas dan kepercayaan diri siswa (Nuryati et al., 2020).

Pembelajaran kedua yang diimplementasikan guru dengan menggunakan aplikasi WhatsApp yang dipadukan pembelajaran berbasis PBL. Proses pelaksanaan pembelajaran yang dikembangkan guru dengan melibatkan peran orang tua, yang disebut Project with parents. Pelibatan orang tua bertujuan untuk mendampingi belajar mandiri yang dilaksanakan di rumah selama pandemik Covid-19. Tugas yang diberikan harus sesuai kondisi dan lingkungan nyata di sekitar rumah dan siswa melaporkan dokumentasi pekerjaan/tugas yang diberikan guru. Pemberian masalah dan pembahasan materi disesuaikan dengan pengalaman seharihari contohnya realistik secara langsung berdasarkan kehidupan sehari-hari (Susanto, 2020). Lebih lanjut Susanto menyatakan pemberian pengalaman belajar secara langsung dapat meningkatkan minat belajar siswa sebesar 92\%. Pembelajaran PBL juga lebih mudah memahami materi dan mampu menghubungkan materi perkuliahan dengan kondisi masyarakat kekinian (Rosidah, 2020). Keunggulan lainnya, penerapan metode PBL dapat meningkatkan hasil belajar IPA siswa kelas IV Sekolah Dasar pembelajaran secara online di masa pandemik Covid-19 (Mulyani, 2020).

Pelaksanaan pembelajaran daring ketiga yang dilaksanakan guru menggunakan aplikasi WhatsApp dengan media video pembelajaran selama pandemik. Media pembelajaran ini berasal dari youtube atau dibuat secara mandiri dengan merekam untuk memudahkan materi pelajaran yang ingin disampaikan kepada siswa. Guru juga meminta mendokumentasi kegiatan dan tugas belajar di rumah seperti hafalan al-quran. Penggunaan video tutorial di masa pandemi virus corona dapat melengkapi sarana pembelajaran daring dan sebagai bahan diskusi, bahan praktek, dan meningkatkan pemahaman siswa terhadap materi yang disampaikan melalui pertemuan daring (Batubara \& Batubara, 2020). Video tutorial yang dibuat oleh guru diunggah lewat WhatsApps dan siswa dapat mengunduh materi dan mempelajari materi dari guru (Anugrahana, 2020). Sebagian besar siswa menyukai aktivitas melihat dan mendengarkan yang berasal dari video pembelajaran (Morgan, 2020). Bahkan pembuatan video dapat dilakukan secara sederhana menggunakan video dan kamera dari handphone guru. Penerapan aplikasi WhatsApp di sekolah dasar masih belum maksimal namun pada penerapan di tingkat universitas sangat populer karena berdasarkan persepsi mahasiswa penggunaan WhatsApp dapat mendukung belajar mahasiswa (Gasaymeh, 2017), meningkatkan sikap dan prestasi belajar (Amry, 2014).

Berdasarkan hasil analisis mendalam peneliti menemukan bahwa pelaksanaan pembelajaran daring berfokus pada proses menyampaikan, berkomunikasi, dan mengumpulkan hasil belajar siswa. Berdasarkan tahapan proses pembelajaran daring selama pandemik Covid-19, hampir seluruh guru sekolah dasar menggunakan aplikasi WhatsApp karena dapat melaksanakan proses pembelajaran secara maksimal. Berikut ini tahap-tahap dalam proses pembelajaran daring menggunakan aplikasi WhatsApp, yakni menyampaikan, berkomunikasi, dan mengumpulkan data.

\section{1) Tahap Menyampaikan}

Prosesnya guru memulai menyampaikan isi materi belajar melalui aplikasi WhatsApp Grup kelas yang beranggotakan guru, siswa bersama orang tua. Dalam pelaksanaannya, guru 
menyampaikan isi materi belajar menggunakan media pembelajaran berupa audio visual dalam bentuk video pembelajaran yang dibuat secara mandiri atau dengan cara mengunduh dari sumber belajar seperti video dari youtube. Semisal memakai media pembelajaran berupa video guru harus menyiapkannya terlebih dahulu sebelum pembelajaran akan dimulai. Hal dapat memudahkan dan membantu para guru untuk menyampaikan materi dengan sebaikbaiknya. Di akhir pembelajaran seorang guru tetap memberikan tugas mandiri dan sekaligus menilai hasil belajar siswanya.

\section{2) Tahap Berkomunikasi}

Guru dalam pembelajaran jarak jauh juga menggunakan grup WhatsApp Kelas sebagai media berkomunikasi dengan orang tua siswa. Hal ini agar siswa dan guru dapat berkomunikasi dalam proses pembelajaran daring. Proses berkomunikasi melalui grup WhatsApp tidak dapat diikuti oleh semua siswa, bagi siswa yang tidak memiliki WhatsApp sering mengalami keterlambatan dalam mengerjakan tugas karena informasi yang diperoleh dari guru sedikit saat berkomunikasi. Oleh karena itu, guru sering meminta kepada siswa yang tidak tergabung dalam grup WhatsApp untuk selalu menanyakan informasi kepada siswa yang memiliki aplikasi WhatsApp.

\section{3) Tahap Mengumpulkan}

Keberadaan grup WA Kelas juga dapat menjadi presensi atau mendata kehadiran siswa selama pembelajaran daring. Siswa dapat menuliskan informasi bahwa siap untuk mengikuti proses pembelajaran yang akan dilaksanakan guru dalam melalui grup WhatsApp. Setiap materi yang disampaikan guru dikirim melalui melalui grup WhatsApp Kelas, begitu pula dengan hasil pembelajaran atau tugas yang telah diselesaikan siswa dikumpulkan melalui grup WhatsApp kelas dalam bentuk Foto. Bagi siswa yang tidak memiliki hp, boleh meminta bantuan dari teman sekelas dan bisa menanyakan kepada guru secara langsung tentang isi materi dan tugas yang diberikan. Pembelajaran daring melalui grup WhatsApp Kelas juga melibatkan dan bekerja sama dengan orang tua untuk memantau proses pengerjaan tugas siswa selama di rumah. Namun ada juga guru yang meminta siswa untuk melakukan pengumpulan tugas siswa secara percakapan pribadi agar tahu siswa masing-masing yang sudah dan belum mengumpulkan.

Penggunaan aplikasi WhatsApp pada pembelajaran daring dikarenakan memiliki banyak keunggulan selama pandemik berlangsung. Bagi yang memiliki keterbatasan kuota aplikasi WhatsApp dapat sangat efektif digunakan, dimana proses pembelajaran daring tetap berlangsung dengan melibatkan interaksi guru dan siswa serta tidak lepas dari pengawasan orang tua (Astini, 2020). Adanya WhatsApp merupakan aplikasi yang tidak dirancang khusus untuk pembelajaran. Pada praktiknya dukungan dan fasilitas grup WA mampu meningkatkan partisipasi dan hasil belajar peserta didik (Utami \& Utami, 2020). Namun pembelajaran daring menggunakan aplikasi WhatsApp kurang efektif jika penjelasan guru kurang komprehensif dan terlalu sederhana, sulit mengukur aspek afektif dan psikomotorik, sinyal internet, kesibukan orang tua serta latar belakang pendidikan orang tua (Daheri et al., 2020). Berikut ini hasil visualisasi peneliti terhadap penggunaan aplikasi WhatsApp dalam pembelajaran daring. 


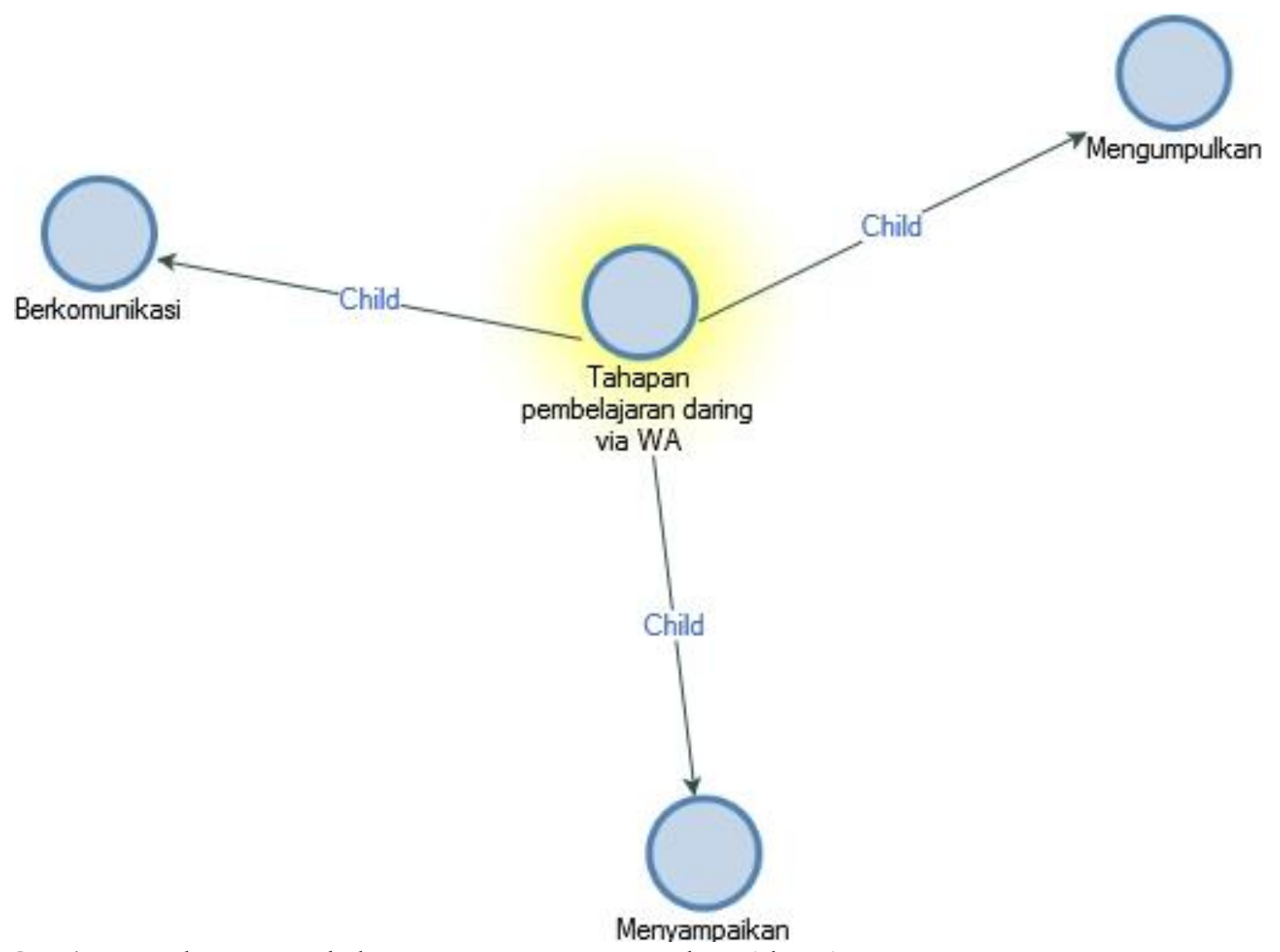

Gambar 2. Tahapan Pembelajaran Daring Menggunakan WhatsApp

Pembelajaran di masa pandemik Covid-19 menuntut guru menjadi lebih inovatif dalam mengemas bahan ajar dan lebih kreatif dalam mengembangkan metode pembelajaran untuk menarik antusiasme siswa. Namun, perlu disesuaikan lagi dengan berbagai kemampuan masing-masing guru, siswa, dan orang tua siswa dalam menyediakan fasilitas pembelajaran online ini, sehingga kendala yang dialami dapat diminimalisir (Lestari \& Gunawan, 2020). Guru harus menciptakan pembelajaran daring yang menarik dan meningkatkan minat belajar siswa dengan cara memberikan motivasi-motivasi belajar melalui perkataan yang positif dan membangun siswa dalam kondisi (Yunitasari \& Hanifah, 2020). Adapun tahapan yang dapat ditambahkan penggunaan WhatsApp di sekolah dapat memastikan interaksi guru dengan siswa melalui kegiatan pengawasan, pemantauan, dan pendampingan yang efektif sebagai bentuk pembelajaran mandiri yang dilaksanakan siswa di rumah (Nel \& Marais, 2020).

\section{Kesimpulan}

Penelitian ini merupakan gambaran prose pembelajaran daring yang dilaksanakan guru sekolah dasar di Bogor dengan memberikan informasi bahwa kegiatan pembelajaran tetap berlangsung dengan perangkat atau aplikasi pembelajaran daring utama guru yakni, WhatsApp. Guru mampu memberikan inovasi pembelajaran dengan cara memadukan aplikasi WhatsApp dengan model pembelajaran PjBL, PBL, dan penggunaan media video pembelajaran. Tujuan utama pembelajaran daring yang dikembangkan guru adalah bagaimana proses pembelajaran tetap berlangsung antara guru dan siswa untuk dapat mencapai hasil belajar semaksimal mungkin dengan berbagai model dan metode pembelajaran. Selain itu, temuan baru proses pelaksanaan pembelajaran daring terutama 
dengan aplikasi WhatsApp mampu melalui tujuan berkomunikasi, penyampaian, dan pengumpulan tugas belajar siswa SD.

\section{Daftar Pustaka}

Abidin, Z., Rumansyah, R., \& Arizona, K. (2020). Pembelajaran Online Berbasis Proyek Salah Satu Solusi Kegiatan Belajar Mengajar Di Tengah Pandemi Covid-19. Jurnal Ilmiah Profesi Pendidikan, 5(1), 64-70. https:// doi.org/10.29303/jipp.v5i1.111

Adedoyin, O. B., \& Soykan, E. (2020). Covid-19 pandemic and online learning: the challenges and opportunities. Interactive Learning Environments, 0(0), 1-13. https:/ / doi.org/10.1080/10494820.2020.1813180

Altaftazani, D. H., Arga, H. S. P., Kelana, J. B., \& Ruqoyyah, S. (2020). Analisis Pembelajaran Daring Membuat Seni Kolase Menggunakan Model Project Based Learning pada Masa Pandemi Covid 19. P2M STKIP Siliwangi Jurnal Ilmiah UPT P2M STKIP Siliwangi, 7(2), 185191.

Amry, A. B. (2014). The impact of WhatApp mobile social learning on the achievement and attitudes of female students compared with face to face learning in the classroom. European Scientific Journal, 10(22), 116-136. http://eujournal.org/index.php/esj/article/view/3909

Annamalai, N. (2019). Using Whatsapp To Extend Learning. Teaching English with Technology, 19(1), 3-20. https://content.ebscohost.com/ContentServer.asp?EbscoContent=dGJyMNHr7ESeprI4 zdnyOLCmsEieprdSs6m4S66WxWXS\&ContentCustomer=dGJyMPGssVGup7VRuePfge yx9Yvf5ucA\&T=P\&P=AN\&S=R\&D=eue\&K=134817798

Anugrahana, A. (2020). Hambatan, Solusi dan Harapan: Pembelajaran Daring Selama Masa Pandemi Covid-19 Oleh Guru Sekolah Dasar. Jurnal Scholaria, 10(3), 282-289.

Astini, N. K. S. (2020). Pemanfaatan teknologi informasi dalam pembelajaran tingkat sekolah dasar pada masa pandemi covid-19. JURNAL LAMPUHYANG LEMBAGA PENJAMINAN MUTU STKIP AGAMA HINDU AMLAPURA, 11(2), 13-25.

Batubara, H. H., \& Batubara, D. S. (2020). Penggunaan Video Tutorial Untuk Mendukung Pembelajaran Daring Di Masa Pandemi Virus Corona. Muallimuna: Jurnal Madrasah Ibtidaiyah, 5(2), 21. https:/ / doi.org/10.31602/muallimuna.v5i2.2950

Carrillo, C., \& Flores, M. A. (2020). COVID-19 and teacher education: a literature review of online teaching and learning practices. European Journal of Teacher Education, 43(4), 466487. https:// doi.org/10.1080/02619768.2020.1821184

Creswell, J. W. (2014). RESEARCH DESIGN: Qualitative, Quantitative, and Mixed Methods Approaches. http://library1.nida.ac.th/termpaper6/sd/2554/19755.pdf

Daheri, M., Juliana, Deriwanto, \& Amda, A. D. (2020). Efektifitas WhatsApp sebagai Media Belajar Daring. Jurnal Basicedu, 3(2), 524-532. https:/ / doi.org/10.31004/ basicedu.v4i4.445

Dewi, W. A. F. (2020). Dampak COVID-19 terhadap Implementasi Pembelajaran Daring di Sekolah Dasar. Edukatif: Jurnal Ilmu Pendidikan, 2(1), 55-61. https://doi.org/10.31004/edukatif.v2i1.89

Elareshi, M., Ziani, A. K., \& Al Shami, A. (2020). Deep learning analysis of social media content used by Bahraini women: WhatsApp in focus. Convergence. https:/ /doi.org/10.1177/1354856520966914 
Gasaymeh, A.-M. (2017). University Students' use of Whatsapp and their Perceptions Regarding its Possible Integration into their Education. Global Journal of Computer Science and Technology, 17(1), 1-9.

Handarini, O. I., \& Wulandari, S. S. (2020). Pembelajaran Daring sebagai Upaya Study From Home (SFH) selama Pandemi Covid 19. Jurnal Pendidikan Administrasi Perkantoran (JPAP), 8(3). https://doi.org/10.1093/fampra/cmy005

Hanik, E. U. (2020). Self Directed Learning Berbasis Literasi Digital Pada Masa Pandemi Covid19 Di Madrasah Ibtidaiyah. ELEMENTARY: Islamic Teacher Journal, 8(1), 183. https:/ / doi.org/10.21043/elementary.v8i1.7417

Jamilah, J. (2020). Guru profesional di era new normal: Review peluang dan tantangan dalam pembelajaran daring. Premiere Educandum: Jurnal Pendidikan Dasar Dan Pembelajaran, 10(2), 238. https:// doi.org/10.25273/ pe.v10i2.7494

Kruszewska, A., Nazaruk, S., \& Szewczyk, K. (2020). Polish teachers of early education in the face of distance learning during the COVID-19 pandemic-the difficulties experienced and suggestions for the future. Education 3-13, 0(0), 1-12. https://doi.org/10.1080/03004279.2020.1849346

Lestari, P. A. S., \& Gunawan. (2020). The Impact of Covid-19 Pandemic on Learning Implementation of Primary and Secondary School Levels. Indonesian Journal of Elementary and Childhood Education, 1(2), 54-58.

Malyana, A. (2020). Pelaksanaan Pembelajaran Daring dan Luring Dengan Metode Bimbingan Berkelanjutan Pada Guru Sekolah Dasar Di Teluk Betung Utara Bandar Lampung. Jurnal Ilmiah Pendidikan Dasar Indonesia, 2(1), 67-76.

Morgan, H. (2020). Best Practices for Implementing Remote Learning during a Pandemic. The Clearing House: A Journal of Educational Strategies, Issues and Ideas, 93(3), 135-141. https:/ / doi.org/10.1080/00098655.2020.1751480

Mulyani, S. (2020). Penerapan Metode Pembelajaran Problem Based Learning Guna Meningkatkan Hasil IPA di Masa Pandemi Covid 19. Navigation Physics: Journal of Physics Education, 2(2), 84-89.

Nel, C., \& Marais, E. (2020). Preservice teachers use of WhatsApp to explain subject content to school children during the COVID-19 pandemic. International Journal of Work-Integrated Learning, 21(5), 629-641.

Nihayati, A., \& Indriani, L. (2021). Efl Students' Perspective on Whatsapp As Media of Online Teaching and Learning in Covid-19 Pandemic. Journal of Research on Language Education, 2(1), 44. https://doi.org/10.33365/jorle.v2i1.898

Nuryati, D. W., Masitoh, S., \& Arianto, F. (2020). Pengaruh Project Based Learning Terhadap Kreativitas Peserta Didik di Masa Pandemi. Educate : Jurnal Teknologi Pendidikan, 5(2), 98106. https:// doi.org/10.32832/educate.v5i2.3375

Purwasih, R., Komala, \& Santana, F. D. T. (2020). Persepsi Mahasiswa Calon Pendidik terhadap Pembelajaran Daring Berbasis ICT pada Masa Pandemik Covid-19. Edumatica:Jurnal Pendidikan Matematika, 10(02), 10-18.

Riyana, C. (2015). Produksi Bahan Pembelajaran Berbasis Online. Modul Pembelajaran Universitas Terbuka Tangerang Selatan, 1-43.

Rosidah, C. T. (2020). Teknik Literasi Silang Dalam Model Problem Based Learning: Alternatif Pembelajaran di Masa Pandemi Covid19. Inventa: Jurnal Pendidikan Guru Sekolah Dasar, 
04(2).

http://jurnal.unipasby.ac.id/index.php/jurnal_inventa/article/download/2730/2229

Ruhimat, T. (2010). Prosedur Pembelajaran. In Upi (pp. 1-30). http:// file.upi.edu/Direktori/FIP/JUR._KURIKULUM_DAN_TEK._PENDIDIKAN/19 5711211985031-TOTO_RUHIMAT/Prosedur_pembelajaran_di_SD.pdf

Sadikin, A., \& Hamidah, A. (2020). Pembelajaran Daring di Tengah Wabah Covid-19:(Online Learning in the Middle of the Covid-19 Pandemic). Biodik, 6(2), 214-224.

Santika, I. W. E. (2020). Pendidikan Karakter pada Pembelajaran Daring. Indonesian Values and Character Education Journal, 3(1), 8-19.

Satrianingrum, A. P., \& Prasetyo, I. (2020). Persepsi Guru Dampak Pandemi Covid-19 terhadap Pelaksanaan Pembelajaran Daring di PAUD. Jurnal Obsesi : Jurnal Pendidikan Anak Usia Dini, 5(1), 633. https:// doi.org/10.31004/obsesi.v5i1.574

Sukandi, A., \& Maulana, P. (2020). Peningkatan Motivasi Siswa dalam Pembelajaran IPA Dengan Menerapkan Metode Demontrasi dan Alat Peraga Sebagai Media Pembelajaran di SD. Jurnal Elementaria Edukasia, 3(2).

Susanto, S. (2020). Efektifitas Small Group Discussion Dengan Model Problem Based Learning Dalam Pembelajaran Di Masa Pandemi Covid-19. Jurnal Pendidikan Modern, 6(1), 55-60. https://doi.org/10.37471/jpm.v6i1.125

Prasetyo, T., Widyasari, \& Hartono, R. (2016). Pengembangan Inovasi Pendidikan Melalui Blended Learning. Didaktika Tauhidi, 4(2).

Utami, S., \& Utami, P. (2020). Peningkatan Partisipasi Belajar dan Hasil Belajar Peserta Didik Teknik Audio Video di Masa Pandemi Covid-19 dengan WhatsApp Group. ELINVO (Electronics, Informatics, and Vocational Education), 5(1), 75-88.

Wong, R. (2020). When no one can go to school: does online learning meet students' basic learning needs? Interactive Learning Environments, 0(0), 1-17. https:/ / doi.org/10.1080/10494820.2020.1789672

Yunitasari, R., \& Hanifah, U. (2020). Pengaruh Pembelajaran Daring terhadap Minat Belajar Siswa pada Masa COVID 19. Edukatif: Jurnal Ilmu Pendidikan, 2(3), 236-240. 